\title{
Clonal Propagation of Khaya senegalensis: The Effects of Stem Length, Leaf Area, Auxins, Smoke Solution, and Stockplant Age
}

\author{
Catherine Ky-Dembele, ${ }^{1,2}$ Mulualem Tigabu, ${ }^{2}$ Jules Bayala, ${ }^{1,3}$ Patrice Savadogo,, 2 \\ Issaka Joseph Boussim, ${ }^{4}$ and Per Christer Odén ${ }^{2}$ \\ ${ }^{1}$ Département Productions Forestières, Institut de l'Environnement et de Recherches Agricoles (INERA/DPF), 03 BP 7047, \\ Ouagadougou 03, Burkina Faso \\ ${ }^{2}$ Swedish University of Agricultural Sciences SLU, Southern Swedish Forest Research Centre, P.O. Box 49, \\ 23053 Alnarp SLU, Sweden \\ ${ }^{3}$ World Agroforestry Centre, Sahel Node, BP E5118, Bamako, Mali \\ ${ }^{4}$ Unité de Formation et Recherche en Sciences de la Vie et de la Terre, Université de Ouagadougou, 03 BP 7021, \\ Ouagadougou 03, Burkina Faso
}

Correspondence should be addressed to Catherine Ky-Dembele, catherine.dembele@slu.se

Received 22 November 2010; Accepted 12 July 2011

Academic Editor: Kihachiro Kikuzawa

Copyright (C) 2011 Catherine Ky-Dembele et al. This is an open access article distributed under the Creative Commons Attribution License, which permits unrestricted use, distribution, and reproduction in any medium, provided the original work is properly cited.

\begin{abstract}
Khaya senegalensis is a multipurpose African timber species. The development of clonal propagation could improve plantation establishment, which is currently impeded by mahogany shoot borer. To examine its potential for clonal propagation, the effects of cutting length, leaf area, stockplant maturation, auxin, and smoke solution treatments were investigated. Leafy cuttings rooted well (up to $80 \%$ ) compared to leafless cuttings (0\%). Cuttings taken from seedlings rooted well (at least $95 \%$ ), but cuttings obtained from older trees rooted poorly (5\% maximum). The rooting ability of cuttings collected from older trees was improved $(16 \%$ maximum) by pollarding. Auxin application enhanced root length and the number of roots while smoke solution did not improve cuttings' rooting ability. These results indicate that juvenile $K$. senegalensis is amenable to clonal propagation, but further work is required to improve the rooting of cuttings from mature trees.
\end{abstract}

\section{Introduction}

Khaya senegalensis A. Juss. (Meliaceae), commonly known as Senegal mahogany, is an evergreen tree that typically grows to a height of $15-20 \mathrm{~m}$ (up to $35 \mathrm{~m}$ on fertile soils) and has a diameter at breast height of $1.5 \mathrm{~m}$, with a clean bole of 8 $16 \mathrm{~m}$. Its natural distribution extends from Mauritania and Senegal east to northern Uganda, within the rainfall range 650-1300 $\mathrm{mm}$ (and even up to $1800 \mathrm{~mm}$ ) [1]. In Burkina Faso, the northern limit of the natural distribution of $K$. senegalensis is $13^{\circ} 55^{\prime} \mathrm{N}$ within the South-Sahelian zone. It occurs in various habitat types, such as on river banks, and in fields, fallows, and protected woodlands, and its population density increases from North to South, reaching up to 17 trees per hectare [2].
K. senegalensis is a multipurpose tree with a variety of economic and environmental values [1]. It is one of the major timber species in West Africa owing to its hard and fungus- and termite-resistant red wood; it is highly valued for carpentry, joinery, furniture, ship building, and as a decorative veneer. The bark is used in traditional medicine to treat malaria, diarrhoea, dysentery, anaemia, and so forth. Recently, the stem bark has been found to contain chemicals (limonoids) that exhibit antiproliferative activity against human cancer cell lines [3]. It is also a good source of fodder for cattle, because of its high dry matter but relatively low crude protein content [4], it is also a source of edible and cosmetic oils [1]. In West Africa, the species has become an important urban amenity tree, commonly planted as a roadside or ornamental shade tree. It is also 
increasingly planted in other countries such as South Africa, Egypt, Australia, Sri Lanka, China, Indonesia, Malaysia, and Vietnam for both amenity and timber production [5].

Natural regeneration of $K$. senegalensis is poor [1] as its seeds lose viability after only two or three weeks under natural conditions [6]. The viability of the seeds can be prolonged by drying to a moisture content below $5 \%$ and storing them at a low temperature of around $5^{\circ} \mathrm{C}[7,8]$. $K$. senegalensis is classified as vulnerable on the IUCN 2010 red list of threatened species (International Union for Conservation of Nature) because of overexploitation for timber, fodder, and medicine, and as a result of habitat loss and degradation [1]. Efforts to restore the depleted mahogany resource base on plantations have been thwarted by persistent attacks of the mahogany shoot borer Hypsipyla robusta, which kills the main stem of young trees, causing excessive branching and contributing to mortality and poor quality timber production $[1,9]$.

Several methods have been recommended to contain this insect pest, including mixed planting with resistant species $[10,11]$, overhead shading of saplings, removal of lateral shoots, and chemical treatments $[1,6,9]$. Selection of genetically resistant individuals and cloning them would ensure better establishment of plantations while conserving the germplasm from genetic erosion [11]. Compared to other vegetative propagation techniques, the use of stem cuttings is considered as the most efficient and low-cost method $[12,13]$. But, the success of this technique depends on several factors which influence the rooting success, such as juvenility or age of the stockplant used, position on the stem from which cuttings are taken, leaf area, or stem length. Also treatment of the cuttings including control of environmental condition and application of plant growth regulators has proved useful in determining the rooting success of many species $[12,14,15]$.

Vegetative propagation using leafy stem cuttings has been successful in African mahoganies such as $K$. ivorensis, $K$. anthotheca, Lovoa trichilioides $[6,16]$, and $K$. senegalensis $[9,17,18]$. The results reported for $K$. senegalensis has been obtained in Thailand on juvenile shoot of hedged seedlings where the effects of hedge height, stump height, and plant growth regulators were evaluated. Hedge height at $20-30 \mathrm{~cm}$ from root collar provided greater rooting percentage than $30-50 \mathrm{~cm}$, while cutting position (top, middle, and proximal section of the stump) had no significant effect on cuttings rooting capacity. Plant growth regulators did not affect rooting capacity but induced better root system [17]. Chip budding, cleft grafting, and side-veneer grafting have been successfully used for $K$. senegalensis seedling grafting in Burkina Faso [18]. Microcutting has also been successfully applied to micrografted plants with scions collected from 6year-old trees of K. senegalensis [9]. As in many other tropical tree species [12], the varying results from these studies still leave some scope to improve the techniques such as the effect of leaf area, cutting length, or the rooting success of cuttings collected from mature individuals. In this study, the objective was to determine the effects of cutting length, leaf area, stockplant maturation, auxin application, and aqueous smoke solution on the rooting ability of stem cuttings of $K$. senegalensis.

\section{Materials and Methods}

2.1. Sources and Preparation of Cuttings. Cuttings were collected from four different types of stockplants: 3-8 monthold seedlings, 5- and 15-year-old planted trees and rejuvenated branches of pollarded old trees. Seedlings were raised from seeds purchased from the National Seed Centre (CNSF) collected in 2008 from naturally regenerated tree stands in Tiakaré village within Gourma Province, Burkina Faso. The seedlings were grown in perforated black polythene bags $(7 \mathrm{~cm}$ diameter $\times 25 \mathrm{~cm}$ tall), filled with a mixture of sand, soil, and manure $(2: 2: 1 \mathrm{v} / \mathrm{v} / \mathrm{v})$, outdoors in the nursery of the Forest Productions Department, Environmental and Agricultural Research Institute (INERA) in Ouagadougou, Burkina Faso. Because of an important concern regarding the use of materials of known age, the two mature stockplant donors were both street trees in Ouagadougou: one set of donors from "Avenue Charles de Gaulle" and the other from "Avenue de la Jeunesse", planted in 1994 and 2004, respectively. The rejuvenated stockplants were street trees planted about 100 years ago on "Rue Nongremason" in Ouagadougou and pollarded five or six months before cutting collection.

Leafy shoots were harvested from the seedlings and from the basal branches of trees between 06:00-08:00 h, placed in water to prevent drying before being taken to the laboratory. Leaves were trimmed so that only two leaflets of two opposite leaves remained on the cuttings collected from mature stockplants, and two simple leaves remained on the cuttings from seedlings, unless otherwise stated. The retained leaves and leaflets were cut to a length of $2-3 \mathrm{~cm}$. Cuttings were $10 \mathrm{~cm}$ in length, unless otherwise stated.

The cuttings were kept under intermittent mist on a propagation bed maintained at 70\%-100\% relative humidity monitored with a GP1 data logger in a greenhouse (3 $\times 15 \mathrm{~m}$ ) located at INERA, Ouagadougou, Burkina Faso. The mean minimum and maximum temperatures in the greenhouse during the whole study period were $22^{\circ} \mathrm{C}$ (night) and $37^{\circ} \mathrm{C}$ (day), respectively. The mean quantum flux density was $450 \mu \mathrm{mol} \mathrm{m} \mathrm{m}^{-2} \mathrm{~s}^{-2}$ during daytime, monitored using a Photosynthetically Active Radiation (PAR) light sensor with readout on a LI-19 unit. To minimise fungal attacks, cuttings were soaked in a solution of Ivory $80 \mathrm{WP}$, a fungicide containing $80 \%$ Mancozeb, for $10 \mathrm{~min}$ before planting. The cuttings were then planted at a depth of $2-3 \mathrm{~cm}$ in a rooting medium consisting of a mixture of sterile sand and perlite $(1: 1 \mathrm{v} / \mathrm{v})$ in plastic propagation trays covered with transparent plastic sheets. The cuttings were regularly watered manually to avoid desiccation. The experiments ran for eight weeks.

\subsection{Experimental Designs}

2.2.1. Effects of Cutting Length and Leaf Area. To test the effect of cutting length on rooting ability, leafy cuttings 
were collected from 5-month-old seedlings and randomly allocated to each of four cutting lengths: $5,10,15$, and $20 \mathrm{~cm}$ in a completely randomised design with five replications and six cuttings per replication of each of the four treatments. In total 120 cuttings were used, collected from the shoots of 120 seedlings.

To examine the effect of leaf area on the rooting ability of cuttings, $10 \mathrm{~cm}$ long cuttings were collected from oneyear-old hedged seedlings and randomly allocated to each of four leaf area treatments, $0 \mathrm{~cm}^{2}$ (leafless), and $6-8 \mathrm{~cm}^{2}$ (one leaf with one pair of cut leaflets), $12-16 \mathrm{~cm}^{2}$ (two leaves with two pairs of cut leaflets), and $22-28 \mathrm{~cm}^{2}$ (two leaves with four pairs of cut leaflets) in a completely randomised design with five replications and six cuttings per replication. Two shoots were cut from each of 60 one-year-old hedged seedlings and mixed together before random allocation to the treatments.

\subsubsection{Effects of Stockplant Maturation and Auxin Treatment.} To investigate the effects of donor plant maturation and Indole-3-butyric acid (IBA), cuttings were collected from four types of stockplants (3-month-old seedlings shoots, 5-month-old young sprouts from pollarded old trees, and crown sprouts from 5- and 15-year-old trees). The young sprouts of the pollarded trees are henceforth referred to as "resprouts". A full factorial experiment with a split plot design involving 16 treatments was employed: stockplants (seedling shoots, resprouts of pollarded trees, 5-year and 15-year-old tree crown sprouts $) \times \operatorname{IBA}(0,2500,5000$, $10000 \mathrm{ppm}$ ). Demineralised water was used for dissolving the auxin and served as a control treatment. The four stockplant types were randomly assigned to the main plots, while the four IBA concentrations were tested at the subplot level. Each treatment had seven replicates with six cuttings per replication; thus the total number of cuttings used was 672 . The basal ends of the cuttings were dipped in the IBA solutions for 5 seconds. In total, 168 single-shoot seedlings while eight trees represented each of the three categories of tree (pollarded, 5- and 15-year-old) were used equally for cutting collection and IBA treatment allocation.

To improve further the rooting ability of cuttings from resprouts of pollarded trees, a follow-up experiment was conducted using naphthalene acetic acid (NAA) alone and in combination with IBA. Resprouts and sprouts from seedling donors were compared. Cuttings were collected from two types of stockplants (4-month-old seedling shoots and 6-month resprouts from pollarded trees) and two auxin treatments (NAA and NAA+IBA) at each of four concentrations (1000, 2000, 3000, and $4000 \mathrm{ppm})$, arranged in a split-split plot design with five replications and six cuttings per replication of the 16 treatments. Stockplant donors were randomly assigned as the main plot factors; auxin treatments as sub-plot factors; the four different concentrations as sub-sub-plot factors. The basal ends of the cuttings were dipped in the auxin solutions for 5 seconds. Overall, 30 shoots were cut from each of eight pollarded trees, which were different from those sampled for the previous experiment; 240 single-shoot seedlings were used for cutting collection.
2.2.3. Effects of Smoke Solution. This experiment examined the potential of smoke as an alternative to commercial auxins. Smoke solution was produced according to the method described by Dayamba et al. [19], it involved burning a mixture of dry wood and herbs and allowing the smoke to bubble into a plastic bottle of water for about $10 \mathrm{~h}$. The stock solution (100\%) was then diluted to $80 \%, 60 \%, 40 \%$, $20 \%, 10 \%$, and $5 \%$ concentrations of smoke solution (v/v) while demineralized water served as a control (0\%). Two experiments were performed.

In the first experiment, the basal ends of cuttings collected from 5-month-old seedlings were immersed in 5\% and $10 \%$ smoke solution for $30,60,120,180 \mathrm{~min}$; the results were compared with a water control in a split plot design. Smoke concentrations were tested at the main plot level while the four immersion times were tested at the subplot level. Each treatment was replicated five times with six cuttings per replication. In total, 240 cuttings were used, collected from 240 single-shoot seedlings.

In the second experiment, $0,20,40,60,80$, and $100 \%$ smoke solutions were tested in a completely randomised design. Five replicates of six cuttings collected from 8month-old single-shoot seedlings were randomly assigned to each treatment. The bases of the cuttings were immersed in the smoke solutions for $60 \mathrm{~min}$.

2.3. Data Collection and Analysis. After eight weeks, the root systems were gently washed and the number of roots measuring at least $1 \mathrm{~mm}$ long was determined for each cutting. The length of the longest root was measured and the secondary roots originating from the longest root were counted. The percentage of rooted cuttings was determined, that is, rooted cuttings as a proportion of planted cuttings in each experimental unit. Data were checked for normality and subjected to analysis of variance using Statistical Analysis System software (SAS Institute Inc., 2002-2008). As a large number of cuttings failed to produce roots, transformation (SQRT, arcsine, and Johnson) of the variable percentage of rooted cuttings was not successful for normal distribution requirement.

Johnson-transformed data were used for other variables that did not fulfil the requirement of normal distribution. The equal variance requirement was observed from the residual plots obtained from Minitab 15 (Minitab Inc., State College, PA, USA). The dependent variables were mean percentage of rooted cuttings, mean number of roots per rooted cutting, mean number of secondary roots per rooted cutting, and mean length of the longest root per rooted cutting. The GLM procedure was used for completely randomised and split-plot designs experiments while the mixed procedure was used for the split-split-plot design. Means that exhibited significant differences $(P<0.05)$ were further compared using Tukey's multiple comparison test.

\section{Results}

3.1. Effects of Cutting Length and Leaf Area. Cutting length did not significantly affect $(P>0.05)$ any of the traits 
TABLE 1: Effects of cutting length on the percentage of rooted cuttings, the number of roots, the length of the longest root, and the number of secondary roots per rooted cutting of Khaya senegalensis. Means \pm SE (standard error) followed by the same letter(s) are not significantly different at the $5 \%$ level according to Tukey's multiple comparison test.

\begin{tabular}{lcccc}
\hline Length & $\begin{array}{c}\text { Rooting } \\
\text { percentage }\end{array}$ & $\begin{array}{c}\text { No. roots/rooted } \\
\text { cutting }\end{array}$ & $\begin{array}{c}\text { Longest root } \\
\text { length }(\mathrm{cm})\end{array}$ & $\begin{array}{c}\text { No. secondary } \\
\text { roots }\end{array}$ \\
\hline $5 \mathrm{~cm}$ & $53 \pm 16 \mathrm{a}$ & $1.8 \pm 0.3 \mathrm{a}$ & $5.62 \pm 1.38 \mathrm{a}$ & $9.5 \pm 4.1 \mathrm{a}$ \\
$10 \mathrm{~cm}$ & $47 \pm 12 \mathrm{a}$ & $2.0 \pm 0.3 \mathrm{a}$ & $4.10 \pm 1.38 \mathrm{a}$ & $3.9 \pm 2.3 \mathrm{a}$ \\
$15 \mathrm{~cm}$ & $43 \pm 16 \mathrm{a}$ & $1.8 \pm 0.2 \mathrm{a}$ & $4.30 \pm 0.32 \mathrm{a}$ & $3.0 \pm 1.7 \mathrm{a}$ \\
$20 \mathrm{~cm}$ & $63 \pm 3 \mathrm{a}$ & $3.0 \pm 0.6 \mathrm{a}$ & $5.16 \pm 1.05 \mathrm{a}$ & $7.7 \pm 2.0 \mathrm{a}$ \\
\hline
\end{tabular}

evaluated (Table 1). However, leaf area significantly $\left(F_{(3,16)}=\right.$ 6.53; $P=0.004)$ affected the percentage of rooted cuttings. No leafless cuttings rooted and mortality was $93 \%$ within eight weeks (Figure 1). No significant differences were found for any of the parameters evaluated for leafy cuttings with different leaf areas even though cuttings with a leaf area of $22-28 \mathrm{~cm}^{2}$ rooted better $(80 \%)$ than cuttings with leaf areas of $6-8 \mathrm{~cm}^{2}(57 \%)$ and $12-16 \mathrm{~cm}^{2}(50 \%)$.

3.2. Effect of Stockplant Maturation and Auxin. Rooting responses of cuttings varied significantly with stockplant types or donor plant maturation and IBA concentrations (Table 2). Cuttings taken from seedlings rooted significantly better $(99 \%)$ than cuttings from resprouts of old pollarded trees (11\%) and crown shoots of old trees (2\%) (Figure 2) and produced more roots per rooted cutting. The IBA treatment significantly affected the percentage of rooted cuttings, the number of roots per rooted cutting, and the root length. Mean root length did not differ between cuttings from seedlings and resprouts $(3.3 \mathrm{~cm}$ versus $2.7 \mathrm{~cm})$, but was significantly lower $(0.7 \mathrm{~cm})$ for cuttings taken from 5 -yearold trees (Figure 2). Considering all stockplants together, IBA application did not improve the percentage of rooting, but the number of roots per rooted cutting increased considerably with greater IBA concentrations: up to $216 \%$ (Table 3). The number of secondary roots was unaffected by IBA application (Table 2). Significant interactions were identified between stockplant donor and IBA with respect to root length and the number of secondary roots per rooted cutting, with longer roots from cuttings originating from pollarded mature tree resprouts treated with high concentrations of IBA (Table 4, Figure 3).

When cuttings were treated with NAA, significant differences were observed among stockplant types; this was true for NAA alone or in combination with IBA. Cuttings from seedling donors produced a significantly higher percentage of rooted cuttings $\left[F_{(1,60)}=479.03 ; P<0.001\right]$, a greater number of roots per rooted cutting $\left[F_{(1,33)}=18.79 ; P=\right.$ $0.001]$, longer roots $\left[F_{(1,33)}=12.15 ; P=0.001\right]$, and a greater number of secondary roots per rooted cutting $\left[F_{(1,33)}=\right.$ 10.09; $P=0.003$ ] than cuttings from resprouts (Table 5). Cuttings treated with NAA alone had significantly $\left[F_{(1,33)}=\right.$ 6.4; $P=0.0163$ ] longer roots than cuttings treated with a combination of NAA and IBA (Table 5), although the latter treatment tended to increase the number of roots per rooted cutting $\left(F_{(1,33)}=4.05 ; P=0.052\right)$. The interaction between stockplant and auxin significantly $\left[F_{(1,60)}=8.56 ; P=0.005\right]$ influenced the percentage of rooted cuttings. For cuttings taken from resprouts of pollarded mature trees, application of NAA alone improved rooting percentage (12\%) compared to cuttings treated with a combination of NAA and IBA $(0 \%)$. No significant differences were found between auxin treatments in cuttings from seedling stockplants $(79 \pm 5 \%$ versus $88 \pm 3 \%$ for NAA and NAA + IBA treatments, resp.).

3.3. Effect of Smoke Solution. A low concentration (5\%) smoke solution significantly inhibited the rooting of cuttings $\left(F_{(2,8)}=11.59, P=0.004\right)$ and the number of roots per rooted cutting, compared to the control $\left(F_{(2,8)}=11.07, P=0.005\right)$. Time of exposure to smoke solution did not significantly affect the rooting ability of cuttings (Table 6). We did not observe significant interactions between the concentrations of the smoke solution and exposure time. Further exposure of cuttings to low and high smoke solution concentrations had no positive effect on the rooting ability of cuttings (Table 7).

\section{Discussion}

4.1. Effects of Leaf Area and Cutting Length. Successful rooting was restricted to leafy stem cuttings of $K$. senegalensis. This is a common response in tropical trees [12]. The inability of leafless cuttings to root has been associated with the rapid depletion of carbohydrates in stem tissues; in contrast, the concentrations in leafy cuttings tend to increase [20]. This suggests that rooting is dependent on carbohydrates formed and utilised after cuttings have been excised from the donor plant [21]. In addition to providing a source of carbohydrates, the leaf also influences the water status of the cutting. The trimming of leaves minimises water loss via transpiration while allowing sufficient photosynthesis to occur during propagation to enable root development [21, 22]. Our findings are consistent with studies of $K$. ivorensis [6, 16], K. anthotheca [6], Acacia senegal [23], Prunus africana [24], Triplochiton scleroxylon [20], and Allanblackia floribunda [25]. However, in contrast to these previous studies, no optimum leaf area was found in K. senegalensis although cuttings with a retained leaf area of $22-28 \mathrm{~cm}^{2}$ seemed to root better than the others. The lack of significant differences may be due to the available carbohydrate reserves in the larger cuttings used in the present study.

Positive relationships between rooting and cutting length have been reported for a number of tropical tree species, including Triplochiton scleroxylon [26], K. ivorensis [16], and Eucalyptus spp. [27]. Such relationships between cutting length and rooting ability are thought to reflect the importance of carbohydrate reserves stored in the stem, which support adventitious root development [26]. The lack of any pronounced relationship between cutting length and rooting ability may be related to the much larger cuttings used in the present study. Although similar results have been recorded for Triplochiton scleroxylon [28] and Allanblackia floribunda 


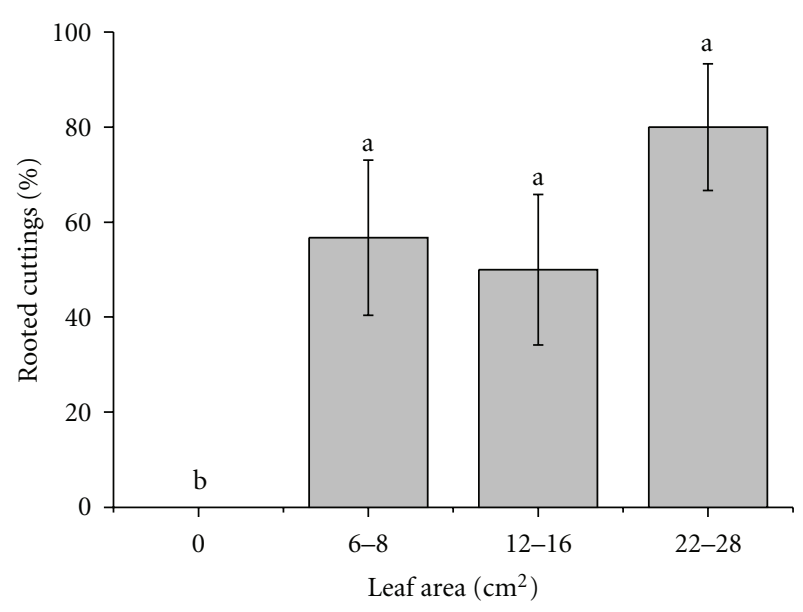

(a)

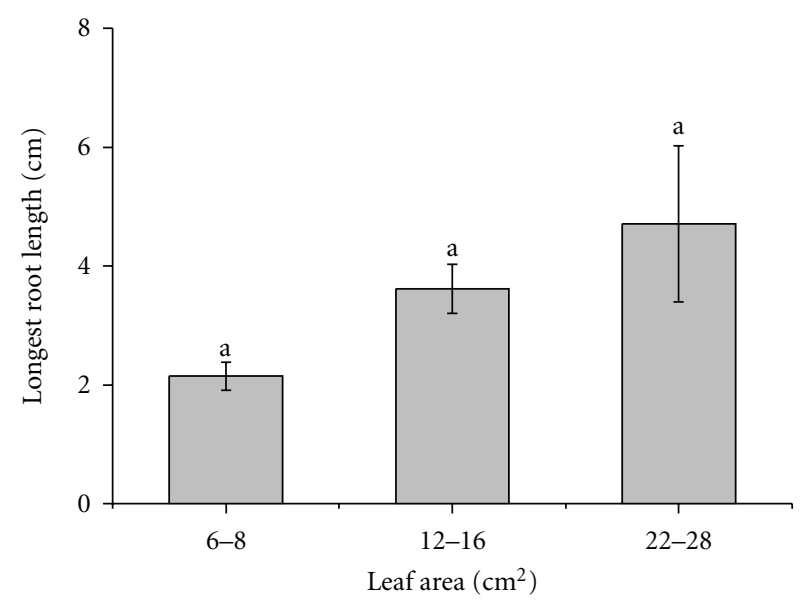

(c)

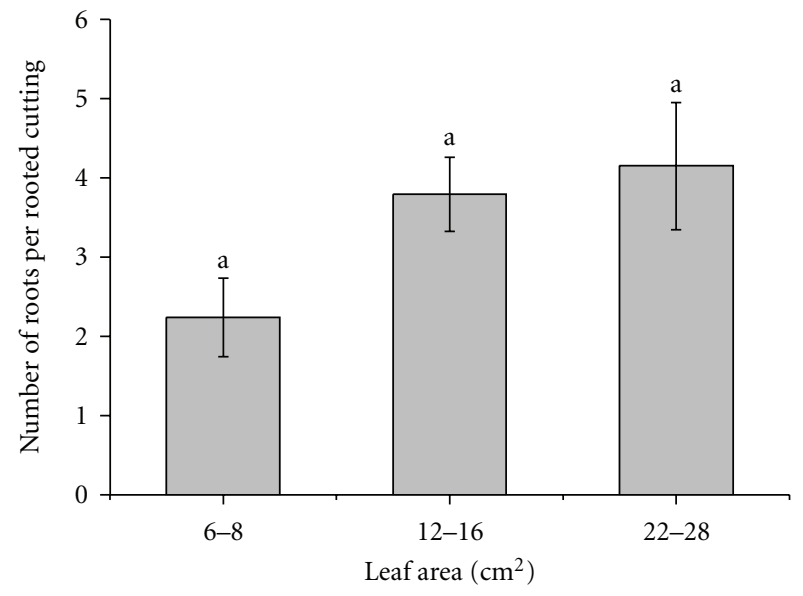

(b)

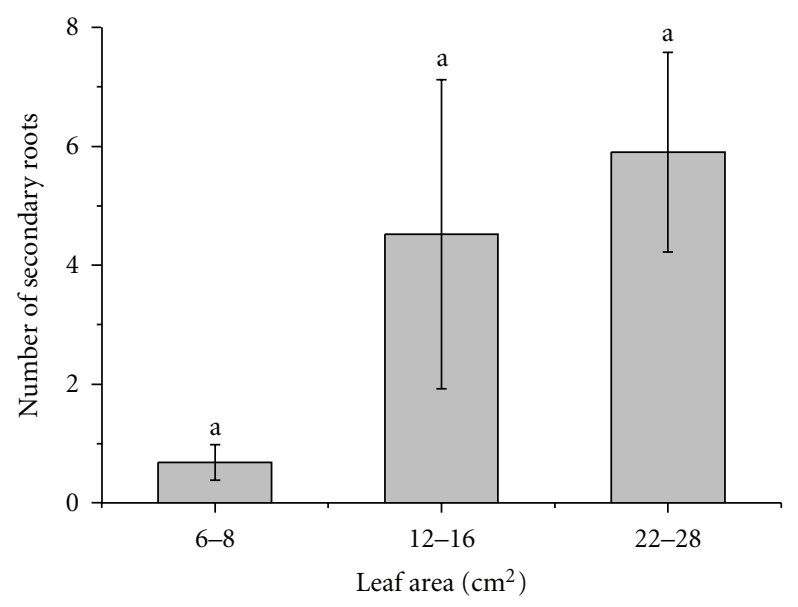

(d)

FIGURE 1: Effect of leaf area on the percentage of rooted cuttings (a), the number of roots per rooted cutting (b), the length of the longest root (c), and the number of secondary roots (d) of Khaya senegalensis. Means followed by the same letter(s) are not significantly different at the $5 \%$ level according to Tukey's multiple comparison test.

TABLE 2: Analysis of variance for the effect of stockplant maturation and IBA treatment on the percentage of rooted cutting (peRC), the number of root per rooted cutting (nbRC), the length of cutting longest root (leRC), and the number of secondary root (nbSR) of Khaya senegalensis.

\begin{tabular}{|c|c|c|c|c|c|c|c|c|c|c|}
\hline \multirow{2}{*}{ Source } & \multicolumn{4}{|c|}{ peRC } & \multicolumn{2}{|c|}{ nbRC } & \multicolumn{2}{|c|}{ leRC $(\mathrm{cm})$} & \multicolumn{2}{|c|}{ nbSR } \\
\hline & DF & $F$ & $P$ & DF & $F$ & $P$ & $F$ & $P$ & $F$ & $P$ \\
\hline Rep & 6 & 0.85 & 0.550 & 6 & 0.94 & 0.543 & 0.33 & 0.896 & 1.12 & 0.466 \\
\hline Stock & 3 & 334.93 & $<0.001$ & 2 & 39.95 & 0.002 & 1.84 & 0.246 & 3.85 & 0.081 \\
\hline \multicolumn{11}{|l|}{ Error: } \\
\hline MS $($ Rep $\times$ Stock $)$ & 18 & & & 5 & & & & & & \\
\hline Rep $\times$ Stock & 18 & 6.35 & $<0.001$ & 5 & 2.39 & 0.071 & 9.3 & $<0.001$ & 3.01 & 0.032 \\
\hline IBA & 3 & 2.75 & 0.049 & 3 & 5.04 & 0.008 & 8.88 & 0.005 & 2.83 & 0.062 \\
\hline Stock $\times$ IBA & 9 & 0.68 & 0.728 & 3 & 1.81 & 0.174 & 8.06 & 0.008 & 3.73 & 0.026 \\
\hline MS (Error) & 72 & & & 22 & & & & & & \\
\hline Total & 111 & & & 42 & & & & & & \\
\hline
\end{tabular}

DF: degrees of freedom; Rep: replicate; stock, stockplant; IBA: Indole 3-butyric acid. 


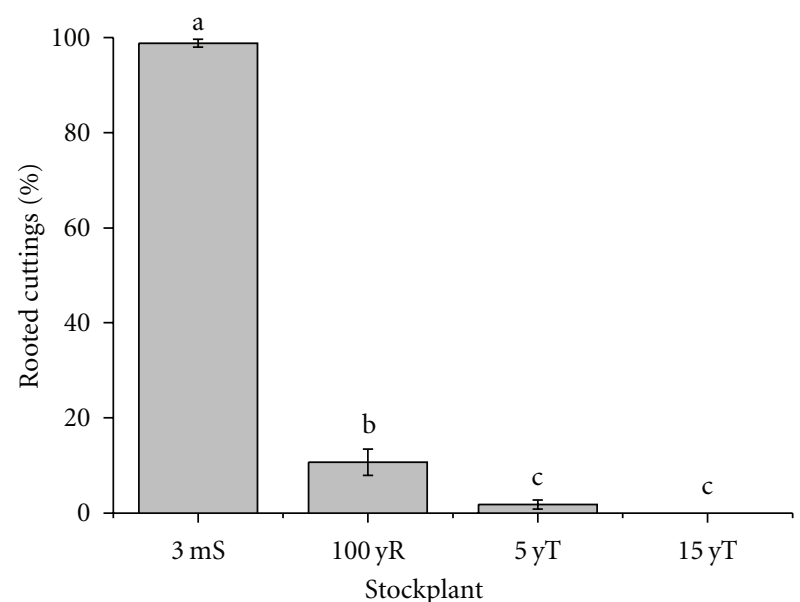

(a)

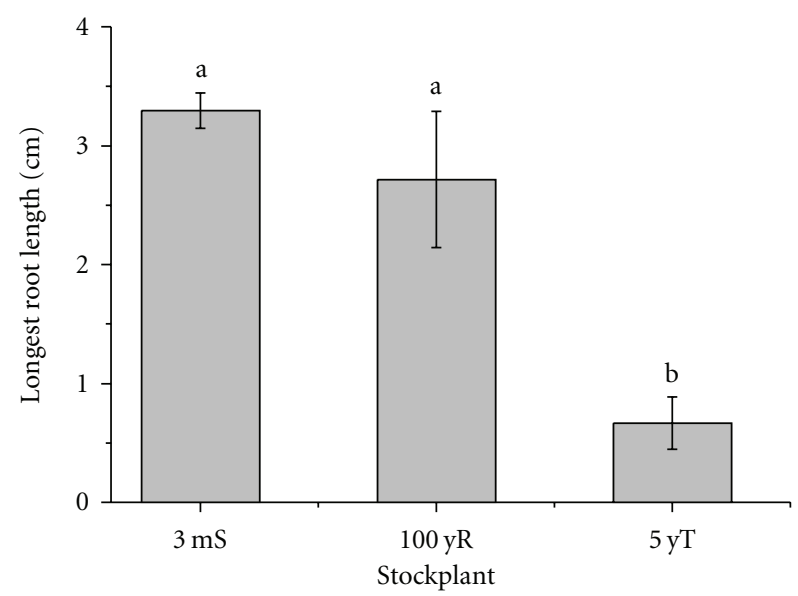

(c)

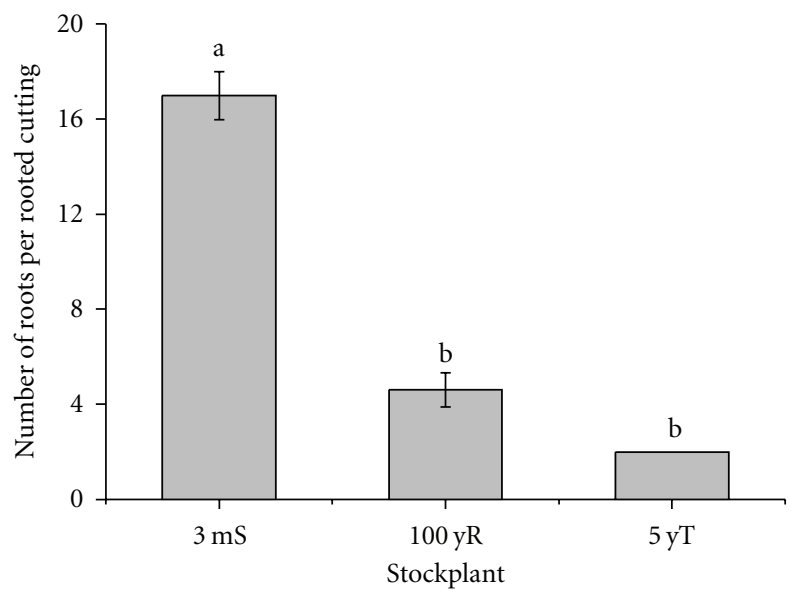

(b)

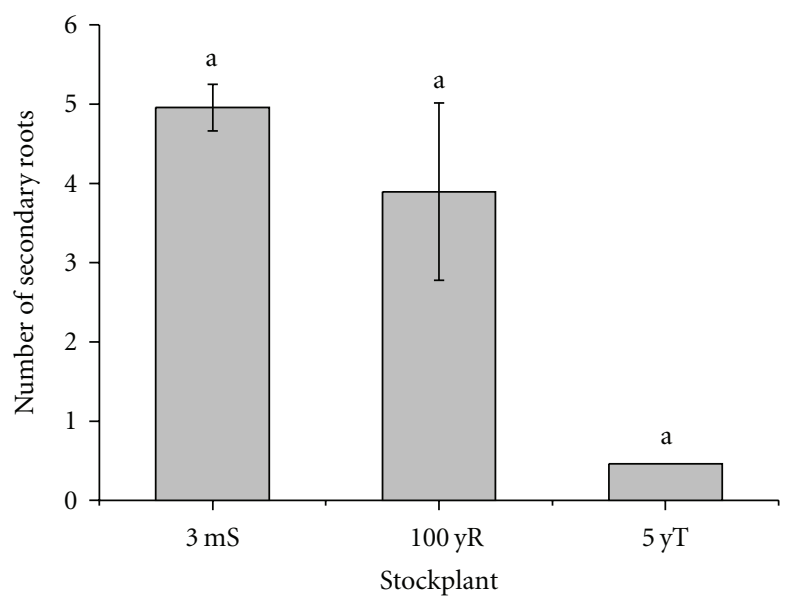

(d)

FIGURE 2: Main effect of stockplant donor on the percentage of rooted cuttings (a), the number of roots per rooted cutting (b), the length of the longest root (c), and the number of secondary roots (d) of Khaya senegalensis. $3 \mathrm{mS}$ : 3-month-old seedling shoots; $100 \mathrm{yR}$ : resprouts of 100 -year-old pollarded trees; 5 yT: crown sprouts of 5-year-old trees; 15 yT: crown sprouts of 15 -year-old trees. Means followed by the same letter(s) are not significantly different at the $5 \%$ level according to Tukey's multiple comparison test.

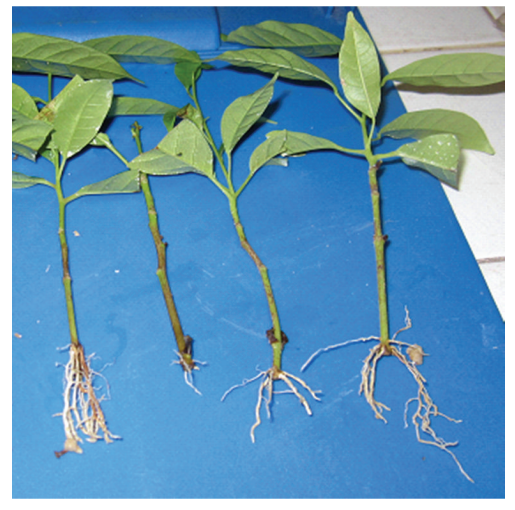

(a)

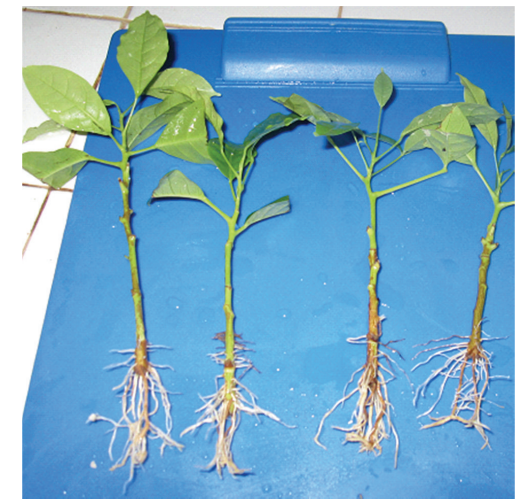

(b)

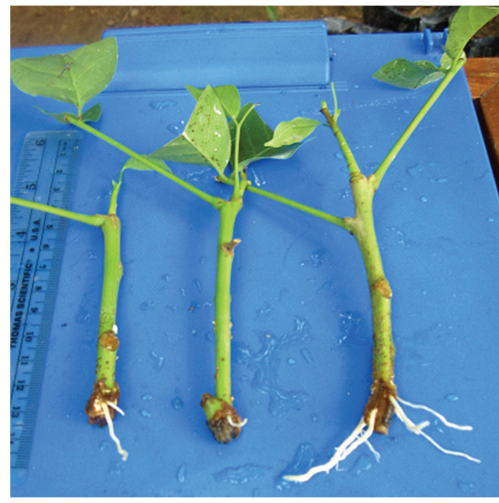

(c)

Figure 3: Root system of cuttings exposed to different concentrations of Indole Butyric Acid: 0 ppm (a) 10000 ppm (b) from 3-month seedlings and $2500 \mathrm{ppm}$ (c) from young sprouts of 100-year-old pollarded trees. 
TABLE 3: Main effects of Indole-3-butyric acid (IBA) on the percentage of rooted cuttings, the number of roots, the length of the longest root, and the number of secondary roots per rooted cutting of Khaya senegalensis. Means \pm SE (standard error) followed by the same letter(s) are not significantly different at the $5 \%$ level according to Tukey's multiple comparison test.

\begin{tabular}{lcccc}
\hline IBA & $\begin{array}{c}\text { Rooting } \\
\text { percentage }\end{array}$ & $\begin{array}{c}\text { No. roots/ } \\
\text { rooted cutting }\end{array}$ & $\begin{array}{c}\text { Longest root } \\
\text { length }(\mathrm{cm})\end{array}$ & $\begin{array}{c}\text { No. secondary } \\
\text { roots }\end{array}$ \\
\hline $0 \mathrm{ppm}$ & $28 \pm 8 \mathrm{ab}$ & $7.9 \pm 1.4 \mathrm{a}$ & $2.59 \pm 0.45 \mathrm{ab}$ & $3.5 \pm 0.9 \mathrm{a}$ \\
$2500 \mathrm{ppm}$ & $30 \pm 8 \mathrm{a}$ & $10.0 \pm 2.1 \mathrm{ab}$ & $2.53 \pm 0.35 \mathrm{~b}$ & $3.8 \pm 0.8 \mathrm{a}$ \\
$5000 \mathrm{ppm}$ & $28 \pm 8 \mathrm{ab}$ & $12.0 \pm 2.1 \mathrm{~b}$ & $3.51 \pm 0.50 \mathrm{a}$ & $4.6 \pm 0.9 \mathrm{a}$ \\
$10000 \mathrm{ppm}$ & $26 \pm 8 \mathrm{~b}$ & $17.1 \pm 3.1 \mathrm{c}$ & $3.27 \pm 0.31 \mathrm{ab}$ & $5.2 \pm 1.0 \mathrm{a}$ \\
\hline
\end{tabular}

TABLE 4: Interactions between stockplant donors and Indole-3-butyric acid (IBA) treatments with respect to the length of the longest root and the number of secondary roots per rooted cutting of Khaya senegalensis. Means \pm SE (standard error) followed by the same letter(s) are not significantly different at the $5 \%$ level according to Tukey's multiple comparison test.

\begin{tabular}{|c|c|c|c|}
\hline Stockplant & IBA (ppm) & $\begin{array}{l}\text { Longest root } \\
\text { length }(\mathrm{cm})\end{array}$ & $\begin{array}{l}\text { No. secondary } \\
\text { roots }\end{array}$ \\
\hline \multirow[t]{4}{*}{ Seedlings } & 0 & $3.30 \pm 0.34 a$ & $4.9 \pm 0.7 \mathrm{ab}$ \\
\hline & 2500 & $3.30 \pm 0.22 \mathrm{a}$ & $5.2 \pm 0.6 \mathrm{ab}$ \\
\hline & 5000 & $3.48 \pm 0.39 a$ & $5.2 \pm 0.8 \mathrm{ab}$ \\
\hline & 10000 & $3.10 \pm 0.24 \mathrm{ab}$ & $4.2 \pm 0.6 \mathrm{ab}$ \\
\hline \multirow[t]{4}{*}{ 5-month resprouts* } & 0 & $1.15 \pm 0.55 b c$ & $0.3 \pm 0.3 b$ \\
\hline & 2500 & $2.08 \pm 0.70 \mathrm{abc}$ & $3.1 \pm 1.8 \mathrm{ab}$ \\
\hline & 5000 & $3.56 \pm 1.33 \mathrm{a}$ & $3.5 \pm 2.0 \mathrm{ab}$ \\
\hline & 10000 & $3.88 \pm 1.37 \mathrm{a}$ & $8.8 \pm 3.8 \mathrm{a}$ \\
\hline \multirow[t]{4}{*}{ 5-year old trees } & 0 & $0.50 \pm 0.00 c$ & 00b \\
\hline & 2500 & $0.75 \pm 0.35 c$ & 00b \\
\hline & 5000 & - & - \\
\hline & 10000 & - & - \\
\hline
\end{tabular}

${ }^{*}$ Young sprouts of 100-year-old pollarded trees.

[29], the data highlight the importance of postseverance over preseverance carbohydrate production [21] in the rooting ability of cuttings, suggesting that leaf area might be more important than cutting length. For example, in K. ivorensis cutting length affected rooting ability only for cuttings with a large leaf area $\left(100 \mathrm{~cm}^{2}\right)$ in contrast to small $\left(10 \mathrm{~cm}^{2}\right)$ and medium $\left(50 \mathrm{~cm}^{2}\right)$ leaf areas [16].

4.2. Effects of Stockplant Maturation and Auxins. The most critical factor affecting vegetative propagation of $K$. senegalensis by stem cuttings was found to be the age of the stockplant. Cuttings taken from 3- and 5-month-old seedlings rooted well and produced more roots than cuttings obtained from older trees. The rooting ability (\% rooting and root number) of older $K$. senegalensis cuttings was marginally improved by pollarding crown branches and by auxin application (16\%) compared to cuttings from unpruned 5-year-old trees (5\%). Cuttings from 15-year-old stockplants did not root at all.

These results are consistent with many previous studies showing that cuttings derived from juvenile stockplants are easier to root than those derived from mature stockplants [30-33] and that shoots originating from juvenile zones of the mature tree exhibit juvenile characteristics $[14,32-$ 34]. The superior rooting ability of cuttings from seedlings over that of trees has been attributed to the effect of changes in the woody plant developmental process that occur with increasing age; these are known as maturation or ontogenetic aging. Ontogenetic aging is often found to be most advanced in the upper parts of a tree and least advanced near the base of the trunk, with intermediate conditions between. As tree species possess meristems that are normally perennially dormant and mature more slowly than active ones, these meristems often produce vigorous sprouts (e.g., stump sprouts) after the release of dormancy [14, 34, 35], but typically these are still difficult to root. The rooting ability of juvenile cuttings may be ascribed to optimum levels of sugars and the total carbohydrate content and low nitrogen levels [33], while the reduction in rooting potential of cuttings from the stem of mature donors might be due to a decrease in the content of endogenous auxins or an accumulation of inhibitory substances [14].

Serial grafting or rooting of cuttings, annual hedging, crown-pruning, and in vitro serial subcultures have been used to reduce the effects of aging. For instance, micrografting on in vitro seedlings of $K$. senegalensis facilitated rooting of microcuttings from 6-year-old trees [9]; annual pruning increased and then maintained the elevated percentage of cuttings that rooted from Douglas fir for a period of up to 14 years [36]; and hedging and repeated cutting enabled 
TABLE 5: Main effects of stockplant maturation, Naphthalene acetic acid (NAA) and NAA in combination with Indole butyric acid (NAA + IBA) on the percentage of rooted cuttings, the number of roots, the length of the longest root, and the number of secondary roots per rooted cutting of Khaya senegalensis. Means \pm SE (standard error) followed by the same letter(s) are not significantly different at the $5 \%$ level according to Tukey's multiple comparison test.

\begin{tabular}{lccccc}
\hline Main effects & & Rooting $(\%)$ & No. roots/rooted cutting & Longest root length $(\mathrm{cm})$ & No. secondary roots \\
\hline Stockplant & Seedlings & $84 \pm 03 \mathrm{a}$ & $9.4 \pm 0.6 \mathrm{a}$ & $2.25 \pm 0.12 \mathrm{a}$ & $1.5 \pm 0.2 \mathrm{a}$ \\
& Resprouts & $6 \pm 02 \mathrm{~b}$ & $2.7 \pm 0.5 \mathrm{~b}$ & $1.31 \pm 0.33 \mathrm{~b}$ & $0.3 \pm 0.3 \mathrm{~b}$ \\
Auxin & NAA & $45 \pm 06 \mathrm{a}$ & $6.7 \pm 0.8 \mathrm{a}$ & $2.18 \pm 0.19 \mathrm{a}$ & $1.3 \pm 0.2 \mathrm{a}$ \\
& NAA + IBA & $44 \pm 07 \mathrm{a}$ & $10.3 \pm 0.8 \mathrm{a}$ & $1.92 \pm 0.13 \mathrm{~b}$ & $1.1 \pm 0.3 \mathrm{a}$ \\
Concentration & $1000 \mathrm{ppm}$ & $42 \pm 10 \mathrm{a}$ & $7.1 \pm 1.0 \mathrm{a}$ & $2.23 \pm 0.28 \mathrm{a}$ & $1.8 \pm 0.5 \mathrm{a}$ \\
& $2000 \mathrm{ppm}$ & $48 \pm 10 \mathrm{a}$ & $9.2 \pm 1.2 \mathrm{a}$ & $2.11 \pm 0.27 \mathrm{a}$ & $0.7 \pm 0.2 \mathrm{a}$ \\
& $3000 \mathrm{ppm}$ & $42 \pm 09 \mathrm{a}$ & $9.0 \pm 1.2 \mathrm{a}$ & $2.20 \pm 0.28 \mathrm{a}$ & $1.4 \pm 0.4 \mathrm{a}$ \\
& $4000 \mathrm{ppm}$ & $48 \pm 10 \mathrm{a}$ & $7.3 \pm 1.4 \mathrm{a}$ & $1.80 \pm 0.20 \mathrm{a}$ & $1.2 \pm 0.3 \mathrm{a}$ \\
\hline
\end{tabular}

TABLE 6: Main effects of low concentrations of smoke solution and immersion time on the percentage of rooted cuttings, the number of roots, the length of the longest root, and the number of secondary roots per rooted cutting of Khaya senegalensis. Means \pm SE (standard error) followed by the same letter(s) are not significantly different at the $5 \%$ level according to Tukey's multiple comparison test.

\begin{tabular}{lccccc}
\hline Main effects & & Rooting Percentage & No. roots/rooted cutting & Longest root length $(\mathrm{cm})$ & No. secondary roots \\
\hline Smoke & $0 \%$ & $100 \pm 0 \mathrm{a}$ & $10 \pm 0.3 \mathrm{a}$ & $2.92 \pm 0.17 \mathrm{a}$ & $4 \pm 0.4 \mathrm{a}$ \\
solution & $5 \%$ & $88 \pm 3 \mathrm{~b}$ & $7 \pm 0.4 \mathrm{~b}$ & $3.28 \pm 0.20 \mathrm{a}$ & $6 \pm 0.8 \mathrm{a}$ \\
& $10 \%$ & $93 \pm 3 \mathrm{ab}$ & $7 \pm 0.3 \mathrm{~b}$ & $3.31 \pm 0.28 \mathrm{a}$ & $5 \pm 0.8 \mathrm{a}$ \\
Immersion & $30 \mathrm{~min}$ & $92 \pm 3 \mathrm{a}$ & $8 \pm 0.4 \mathrm{a}$ & $3.01 \pm 0.25 \mathrm{a}$ & $5 \pm 1 \mathrm{a}$ \\
time & $60 \mathrm{~min}$ & $93 \pm 3 \mathrm{a}$ & $8 \pm 0.6 \mathrm{a}$ & $3.10 \pm 0.24 \mathrm{a}$ & $5 \pm 1 \mathrm{a}$ \\
& $120 \mathrm{~min}$ & $97 \pm 2 \mathrm{a}$ & $8 \pm 0.5 \mathrm{a}$ & $3.22 \pm 0.26 \mathrm{a}$ & $5 \pm 1 \mathrm{a}$ \\
& $180 \mathrm{~min}$ & $91 \pm 4 \mathrm{a}$ & $8 \pm 0.6 \mathrm{a}$ & $3.34 \pm 0.26 \mathrm{a}$ & $6 \pm 1 \mathrm{a}$ \\
\hline
\end{tabular}

TABLE 7: Rooting ability (percentage of rooted cuttings, number of roots, length of the longest root, and number of secondary roots per rooted cutting) of Khaya senegalensis cuttings in response to exposure to various concentrations of smoke solution for one hour. Means \pm SE (standard error) followed by the same letter(s) are not significantly different at the $5 \%$ level according to Tukey's multiple comparison test.

\begin{tabular}{lcccc}
\hline Smoke solution $(\%)$ & Rooting percentage & No. roots/rooted cutting & Longest root length $(\mathrm{cm})$ & No. secondary roots \\
\hline 0 & $47 \pm 6 \mathrm{a}$ & $2.7 \pm 0.4 \mathrm{a}$ & $6.44 \pm 0.75 \mathrm{a}$ & $16.2 \pm 3.8 \mathrm{a}$ \\
20 & $27 \pm 17 \mathrm{a}$ & $2.3 \pm 1.3 \mathrm{a}$ & $7.92 \pm 0.66 \mathrm{a}$ & $8.1 \pm 3.3 \mathrm{a}$ \\
40 & $60 \pm 16 \mathrm{a}$ & $2.0 \pm 0.4 \mathrm{a}$ & $4.32 \pm 0.40 \mathrm{a}$ & $4.1 \pm 1.1 \mathrm{a}$ \\
60 & $53 \pm 14 \mathrm{a}$ & $2.7 \pm 0.6 \mathrm{a}$ & $6.10 \pm 0.59 \mathrm{a}$ & $6.9 \pm 2.9 \mathrm{a}$ \\
80 & $67 \pm 9 \mathrm{a}$ & $2.2 \pm 0.3 \mathrm{a}$ & $3.95 \pm 0.90 \mathrm{a}$ & $7.5 \pm 2.6 \mathrm{a}$ \\
100 & $53 \pm 12 \mathrm{a}$ & $2.4 \pm 0.4 \mathrm{a}$ & $3.99 \pm 1.45 \mathrm{a}$ & $6.7 \pm 2.6 \mathrm{a}$ \\
\hline
\end{tabular}

clonal propagation of Sitka spruce for up to 18 years [37]. Crown pollarding offers the opportunity to select $K$. senegalensis trees with demonstrated resistance or tolerance to mahogany shoot borer attacks. However more work is needed to enhance the rooting ability of cuttings from pollarded mature trees.

Depending on the maturation of the stockplant from which cuttings had been taken, three major effects of auxin on the rooting ability of cuttings were noted: effects on root formation, the number of roots per rooted cutting, and root length. The effectiveness of applied auxin in inducing rooting and in increasing the total number of roots increased with stockplant maturation. For cuttings derived from seedlings, auxin application did not influence root induction; the most significant effect of auxin application was on the number of roots per rooted cutting. Overall root number increased by up to $216 \%$ in cuttings treated with $10000 \mathrm{ppm}$ IBA compared to the control. For cuttings taken from resprouts of pollarded trees, the application of high doses of auxin increased root length and the number of secondary roots. Moreover, good root systems are essential for growth and the survival of stecklings because they increase the volume of soil that can be accessed as a source of water and nutrients. Similar effects have been reported for African mahoganies and other African woody species $[6,13,16,23,24]$.

4.3. Effects of Smoke Solution. It has been reported that aqueous smoke extract stimulates root initiation and development as well as the growth of primary root sections of Lycopersicon esculentum, depending on the dilution of the smoke extracts and immersion time [38]. The active compound in the smoke (butenolide) has been shown to exhibit cytokinin- and auxin-like effects, stimulating cell division in soybean callus and rooting in mung bean [39]. 
However, in the present investigation there was no comparative advantage of applying smoke solution over the control. This discrepancy might be related to the concentration of the initial stock solution and the species-specific nature of the response. But lower doses of smoke solution (5-10\%) were associated with more root induction and a greater number of roots than higher doses. Whether this was related to the age of the seedlings or to the smoke effect requires further investigation. However, the response to low doses of smoke solution indicates that it would be appropriate to explore further its application alone or in combination with other plant growth regulators to enhance the rooting ability of cuttings from juveniles as well as mature donors.

\section{Conclusions}

These results indicate clearly that $K$. senegalensis can be propagated vegetatively from leafy stem cuttings derived from seedlings; success was, however, very limited with cuttings from older plants. With the increasing demand for high-quality timber and raw materials for pharmaceuticals, tree improvement programmes could benefit from our findings, contributing to rapid and mass propagation of $K$. senegalensis. The selection of mahogany shoot borer resistant genotypes within seedling populations could be carried out in order to enhance the establishment of plantations of $K$. senegalensis within its native range in West Africa.

\section{Acknowledgments}

Thanks are due to Swedish International Development Cooperation Agency (Sida) for financial support. Special thanks are given to François Nandweogo, Karim Ouédraogo, Augustin Waneweogo, Rosalie T. A. Dembele, Abou Sanou and Zezouma Sanon for their help in establishing and evaluating the trials; to Modeste Meda and Djibril Dayamba for providing the smoke solution; to Ouagadougou City Hall administrator and Issa Sawadogo for permission to work on the planted roadside trees; to Sees-editing Ltd for linguistic improvements.

\section{References}

[1] A. Nikiema and D. Pasternak, "Khaya senegalensis (Desr.) A. Juss," in Plant Resources of Tropical Africa, D. Louppe, A. A. Oteng-Amoako, and M. Brink, Eds., pp. 339-344, PROTA Foundation, Wageningen, The Netherlands, 2008.

[2] D. Lompo, "Contribution à la mise œuvre d'un programme de conservation et d'amélioration génétique de Khaya senegalensis (Desr.) A. Juss. au Burkina Faso," Faculté Universitaire des Sciences Agronomiques, Gembloux, Belgium, p. 94. 2007.

[3] H. P. Zhang, X. Wang, F. Chen, X. M. Androulakis, and M. J. Wargovich, "Anticancer activity of limonoid from Khaya senegalensis," Phytotherapy Research, vol. 21, no. 8, pp. 731734, 2007.

[4] S. Ouedraogo-Kone, C. Y. Kabore-Zoungrana, and I. Ledin, "Intake and digestibility in sheep and chemical composition during different seasons of some West African browse species," Tropical Animal Health and Production, vol. 40, no. 2, pp. 155164, 2008.
[5] R. Arnold, "Khaya senegalensis - current use from its natural range and its potential in Sri Lanka and elsewhere in Asia," in Prospects for High-Value Hardwood Timber Plantations in the 'Dry' Tropics of Northern Australia, Mareeba, Australia, 2004.

[6] E. Opuni-Frimpong, D. F. Karnosky, A. J. Storer, and J. R. Cobbinah, "Key roles of leaves, stockplant age, and auxin concentration in vegetative propagation of two African mahoganies: Khaya anthotheca Welw. and Khaya ivorensis A. Chev," New Forests, vol. 36, no. 2, pp. 115-123, 2008.

[7] P. Danthu, A. Gaye, and A. Sarr, "Long term storage of Khaya senegalensis seeds," International Tree Crops Journal, vol. 10, no. 2, pp. 93-100, 1999.

[8] C. S. Gamene and E. N. Eriksen, "Storage behaviour of Khaya senegalensis seeds from Burkina Faso," in Comparative Storage Biology of Tropical Tree Seeds, M. Sacande, D. Joker, M. E. Dulloo, and K. A. Thomsen, Eds., pp. 9-15, International Plant Genetic Resources Institute (IPGRI), Rome, Italy, 2005.

[9] P. Danthu, D. Diaite-Sanogo, M. Sagna, P. Sagna, and Y. K. Dia-Gassama, "Micropropagation of khaya senegalensis, an African mahogany from dry tropical zones," Journal of Tropical Forest Science, vol. 15, no. 1, pp. 164-175, 2003.

[10] F. Brunck and B. Mallet, "Les problèmes phytosanitaires de l'Acajou en Cote d'Ivoire," Bois et Forêts des Tropiques, vol. 237, pp. 9-29, 1993.

[11] A. C. Newton, P. Baker, S. Ramnarine, J. F. Mesen, and R. R. B. Leakey, "The mahogany shoot borer: prospects for control," Forest Ecology and Management, vol. 57, no. 1-4, pp. 301-328, 1993.

[12] R. R. B. Leakey, "Physiology of vegetative reproduction," in Encyclopaedia of Forest Sciences, J. Burley, J. Evans, and J. A. Youngquist, Eds., pp. 1655-1668, Academic Press, London, UK, 2004.

[13] Z. Teklehaimanot, H. Tomlinson, T. Lemma, and K. Reeves, "Vegetative propagation of Parkia biglobosa (Jacq) Benth, an undomesticated fruit tree from West Africa," Journal of Horticultural Science and Biotechnology, vol. 71, no. 2, pp. 205215, 1996.

[14] H. T. Hartmann, D. E. Kester, F. T. Davies, and R. L. Geneve, Hartmann and Kester's Plant Propagation: Principles and Practices, Prentice Hall, New Jersey, NJ, USA, 7th edition, 2002.

[15] C. Ky-Dembele, "Clonal Propagation of Detarium microcarpum and Khaya senegalensis - a Step toward Clonal Forestry in Burkina Faso," Diss. Swedish University of Agricultural Sciences, p. 65, 2011.

[16] Z. Tchoundjeu and R. R. B. Leakey, "Vegetative propagation of African Mahogany: effects of auxin, node position, leaf area and cutting length," New Forests, vol. 11, no. 2, pp. 125-136, 1996.

[17] S. Limpiyaprapant, P. Soonhuae, and S. Kijkar, Rooting Ability of khaya senegalensis Cuttings in Relation to Hedge Height and Hormone Application, ASEAN Forest Tree Seed Center, Malaysia, Thailand, 1996.

[18] C. Ouédraogo, "Détermination de méthodes appropriées de greffage de deux espèces forestières locales: acacia senegal et Khaya senegalensis," in Centre Agricole Polyvalent, p. 44, Centre National de Semences Forestières, Ouagadougou, Burkina Faso, 2004.

[19] S. D. Dayamba, L. Sawadogo, M. Tigabu et al., "Effects of aqueous smoke solutions and heat on seed germination of herbaceous species of the Sudanian savanna-woodland in Burkina Faso," Flora, vol. 205, no. 5, pp. 319-325, 2010.

[20] R. R. B. Leakey, V. R. Chapman, and K. A. Longman, "Physiological studies for tropical tree improvement and 
conservation. Factors affecting root initiation in cuttings of Triplochiton scleroxylon K. Schum," Forest Ecology and Management, vol. 4, no. 1, pp. 53-66, 1982.

[21] R. R. B. Leakey and M. P. Coutts, "The dynamics of rooting in Triplochiton scleroxylon cuttings - their relation to leaf-area, node position, dry-weight accumulation, leaf water potential and carbohydrate composition," Tree Physiology, vol. 5, no. 1, pp. 135-146, 1989.

[22] F. Mesen, A. C. Newton, and R. R. B. Leakey, "The effects of propagation environment and foliar area on the rooting physiology of Cordia alliodora (Ruiz \& Pavon) Oken cuttings," Trees - Structure and Function, vol. 11, no. 7, pp. 404-411, 1997.

[23] S. Badji, I. Ndiaye, P. Danthu, and J. P. Colonna, "Vegetative propagation studies of gum arabic trees. 1. Propagation of Acacia senegal (L.) Willd. using lignified cuttings of small diameter with 8 nodes," Agroforestry Systems, vol. 14, no. 3, pp. 183-191, 1991.

[24] Z. Tchoundjeu, M. L. Avana, R. R. B. Leakey et al., "Vegetative propagation of Prunus africana: effects of rooting medium, auxin concentrations and leaf area," Agroforestry Systems, vol. 54, no. 3, pp. 183-192, 2002.

[25] A. R. Atangana, Z. Tchoundjeu, E. K. Asaah, A. J. Simons, and D. P. Khasa, "Domestication of Allanblackia floribunda: amenability to vegetative propagation," Forest Ecology and Management, vol. 237, no. 1-3, pp. 246-251, 2006.

[26] R. R. B. Leakey and H. R. S. Mohammed, "The effects of stem length on root initiation in sequential single-node cuttings of Triplochiton scleroxylon K. Schum," Journal of Horticultural Science, vol. 60, no. 3, pp. 431-437, 1985.

[27] R. D. Naidu and N. B. Jones, "The effect of cutting length on the rooting and growth of subtropical Eucalyptus hybrid clones in South Africa," Southern Forests, vol. 71, no. 4, pp. 297-301, 2009.

[28] T. Nketiah, A. C. Newton, and R. R. B. Leakey, "Vegetative propagation of Triplochiton scleroxylon K. Schum in Ghana," Forest Ecology and Management, vol. 105, no. 1-3, pp. 99-105, 1998.

[29] A. R. Atangana and D. P. Khasa, "Preliminary survey of clonal variation in rooting of Allanblackia floribunda leafy stem cuttings," Canadian Journal of Forest Research, vol. 38, no. 1, pp. 10-15, 2008.

[30] R. D. Browne, C. G. Davidson, T. A. Steeves, and D. I. Dunstan, "Effects of ortet age on adventitious rooting of jack pine (Pinus banksiana) long-shoot cuttings," Canadian Journal of Forest Research, vol. 27, no. 1, pp. 91-96, 1997.

[31] D. Berhe and L. Negash, "Asexual propagation of Juniperus procera from Ethiopia: a contribution to the conservation of African pencil cedar," Forest Ecology and Management, vol. 112, no. 1-2, pp. 179-190, 1998.

[32] E. Amri, H. V. M. Lyaruu, A. S. Nyomora, and Z. L. Kanyeka, "Vegetative propagation of African Blackwood (Dalbergia melanoxylon Guill. \& Perr.): effects of age of donor plant, IBA treatment and cutting position on rooting ability of stem cuttings," New Forests, vol. 39, no. 2, pp. 183-194, 2010.

[33] D. R. Bhardwaj and V. K. Mishra, "Vegetative propagation of Ulmus villosa: effects of plant growth regulators, collection time, type of donor and position of shoot on adventitious root formation in stem cuttings," New Forests, vol. 29, no. 2, pp. 105-116, 2005.

[34] J. M. Bonga and P. von Aderkas, "Rejuvenation of tissues from mature conifers and its implications for propagation in vitro," in Clonal Forestry I, Genetics and Biotechnology, M. R.
Ahuja and W. J. Libby, Eds., pp. 182-199, Springer, Berlin Heidelberg, Germany, 1993.

[35] M. S. Greenwood and K. W. Hutchison, "Maturation as a developmental process," in Clonal forestry I, Genetics and Biotechnology, M. R. Ahuja and W. J. Libby, Eds., pp. 14-33, Springer, Berlin Heidelberg, Germany, 1993.

[36] D. L. Copes, "Effects of long-term pruning, meristem origin, and branch order on the rooting of Douglas-Fir stem cuttings," Canadian Journal of Forest Research, vol. 22, no. 12, pp. 1888-1894, 1992.

[37] W. L. Mason, M. I. Menzies, and P. Biggin, "A comparison of hedging and repeated cutting cycles for propagating clones of Sitka spruce," Forestry, vol. 75, no. 2, pp. 149-162, 2002.

[38] J. L. S. Taylor and J. van Staden, "Plant-derived smoke solutions stimulate the growth of Lycopersicon esculentum roots in vitro," Plant Growth Regulation, vol. 26, no. 2, pp. 7783, 1998.

[39] N. Jain, W. A. Stirk, and J. Van Staden, "Cytokinin-and auxin-like activity of a butenolide isolated from plant-derived smoke," South African Journal of Botany, vol. 74, no. 2, pp. 327-331, 2008. 

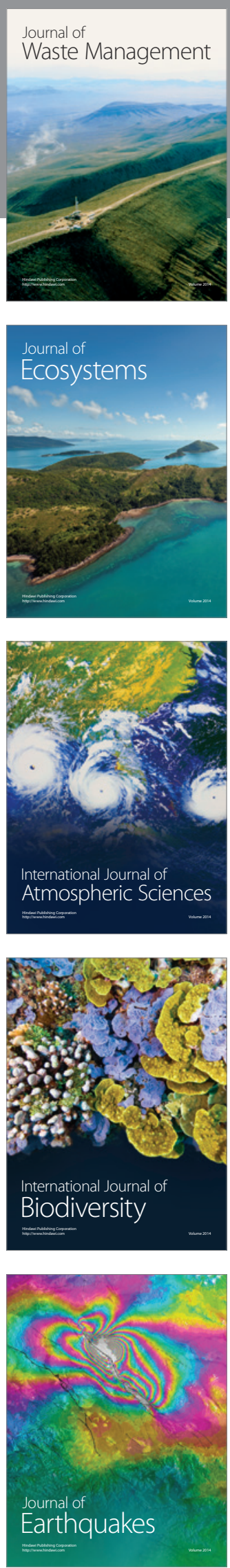
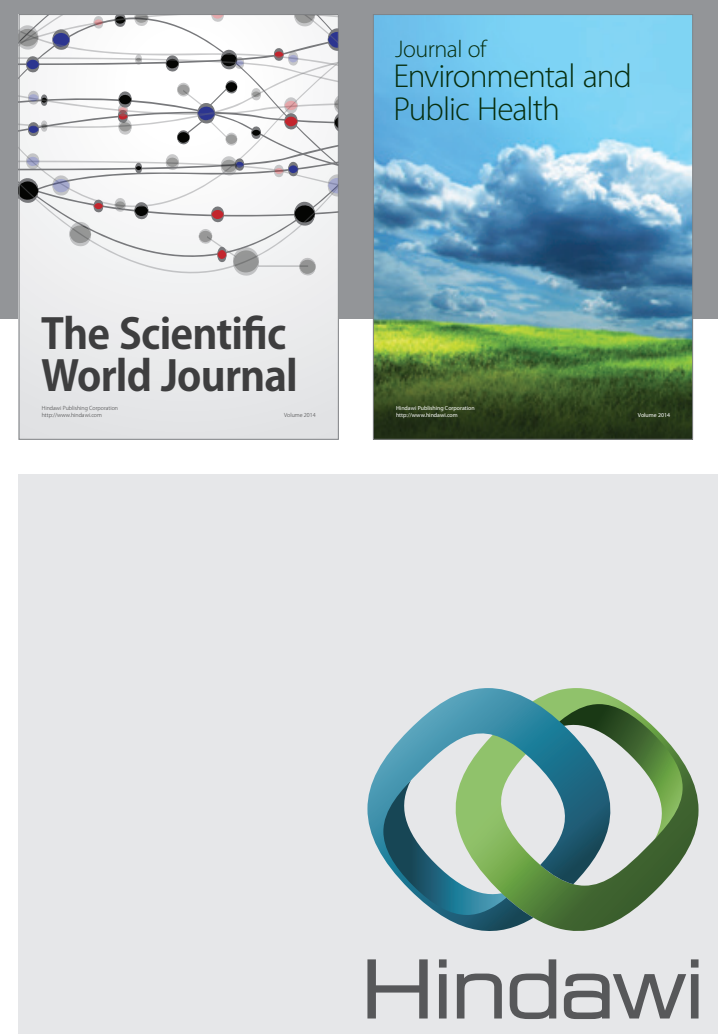

Submit your manuscripts at

http://www.hindawi.com
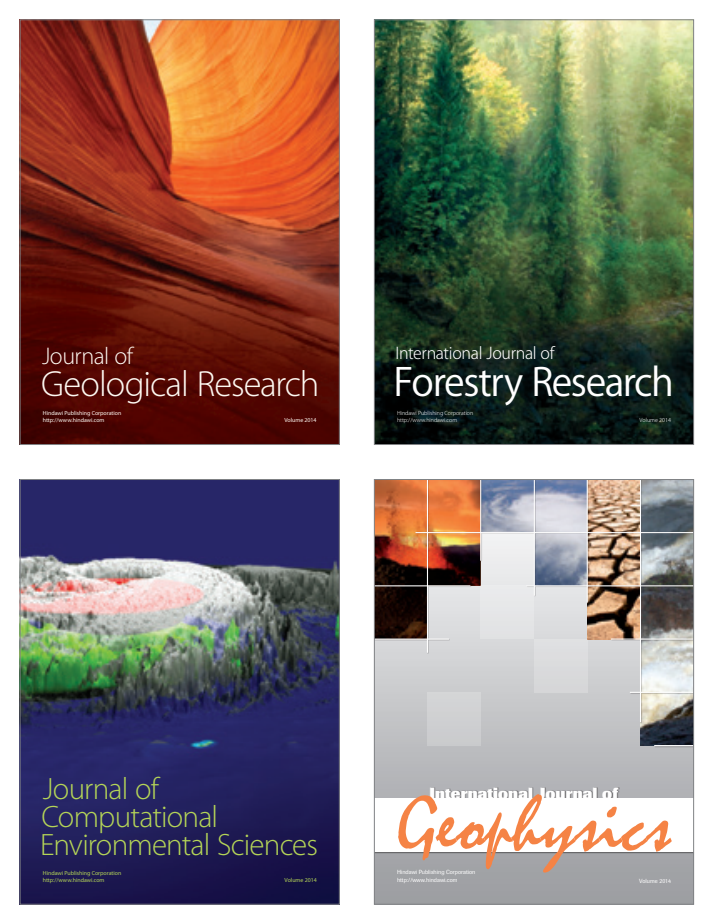
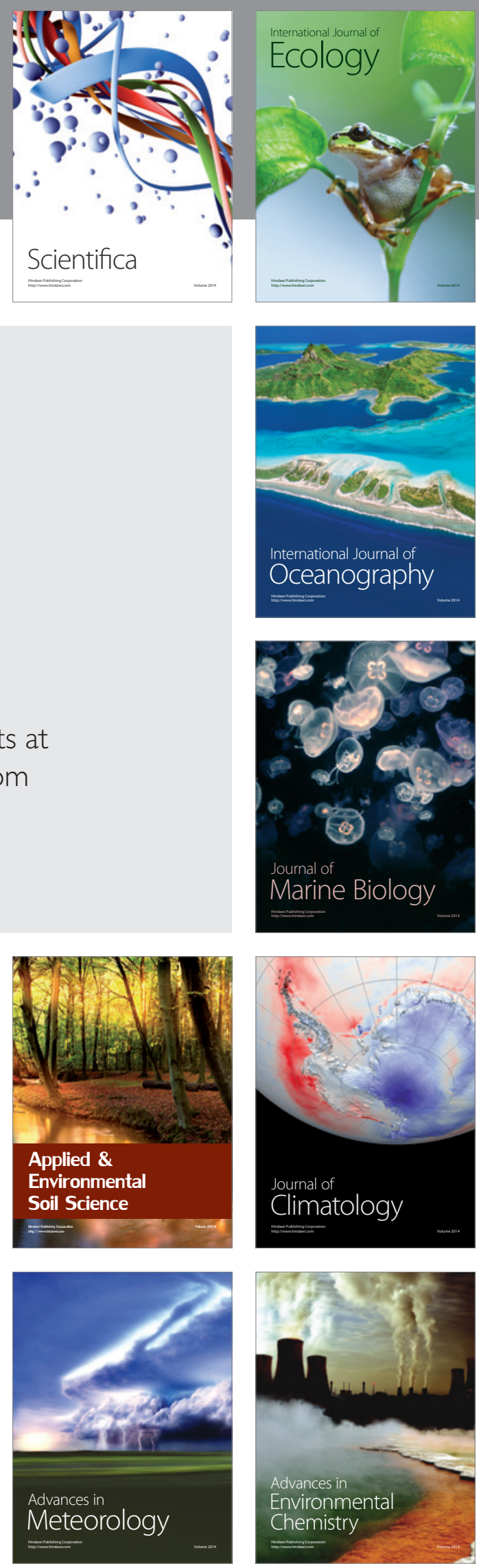